\title{
MEASURING THE EXTENT OF THE ENVIRONMENTAL POLLUTION IN THE WATERS OF THE AL-DIWANI RIVER BY CERTAIN TRACE ELEMENTS RESULTING FROM AL-DIWANI TEXTILE FACTORY USING SPECTROSCOPIC METHODS
}

\author{
Mohauman Mahammad AL-RUFAIE * \\ * Kufa University, College of Science, Chemistry Department, Kufa Street 1, Najaf, Iraq, \\ IQ-009 67809086646, muhaimin.alrufaie@uokufa.edu.iq
}

DOI: 10.1515/trser-2015-0081

KEYWORDS: textile factory, Al-Diwani River, trace elements, Iraq.

\section{ABSTRACT}

The textile industry is a key source of pollution in fresh water. The concentration of key heavy metal pollutants (cobalt, nickel, lead, mercury, cadmium, copper, and iron) as well as $\mathrm{pH}$ value and conductivity were measured in water samples taken from the input and output (waste water) of Al-Diwani textile factory on the Al-Diwani River, Iraq. These samples were measured using two methods, flame atomic absorption spectrophotometry and spectrometry. This paper considers the relative effectiveness of each method for measuring the concentrations of the elements, and discusses which method is best for which element. It was found that the first method is more accurate for measuring the concentrations for all elements except iron.

RÉSUMÉ: La détermination par des méthodes spectroscopiques de la pollution dans les eaux de la rivière de $\mathrm{Al}$-Diwani avec certains éléments-trace provenant de l'usine textile de Al-Diwani.

L'industrie textile est une importante source de pollution de l'eau douce. La concentration des polluants de la catégorie des métaux lourds (cobalt, nickel, plomb, mercure, cadmium, cuivre et fer), ainsi que le $\mathrm{pH}$ et la conductivité ont été mesurés dans des échantillons d'eau pris à l'entrée et à la sortie (eaux usées) de l'eau dans l'usine textile AlDiwani située sur la rivière Al-Diwani en Iraq. Les concentrations des éléments mentionnés cidessus ont été déterminées par deux méthodes: la spectrophotométrie d'absorption atomique sur flamme et la spectrométrie. Cet article se penche sur l'efficacité relative de chaque méthode pour déterminer les concentrations des éléments et discute quelle est la meilleure méthode pour chaque élément. Dans le cas de tous les éléments, sauf le fer, la première méthode a été prouvée comme plus précise pour mesurer les concentrations.

REZUMAT: Măsurarea prin metode spectroscopice a nivelului de poluare a apelor râului Al-Diwani cu anumiți contaminanți proveniți de la fabrica de textile Al-Diwani.

Industria textilă este o sursă importantă de poluare a apei dulci. Concentrația poluanţilor din clasa metale grele (cobalt, nichel, plumb, mercur, cadmiu, cupru şi fier) precum şi $\mathrm{pH}$-ul şi conductivitatea au fost măsurate în probe de apă recoltate la intrarea şi ieşirea folosinţei de apă a fabricii de textile Al-Diwani, situată pe râul Al-Diwani din Irak. Probele au fost determinate prin două metode: spectrofotometria prin absorbţie atomică pe flacără şi spectrometria. Prezentul studiu analizează eficacitatea relativă a fiecărei metode în măsurarea concentraţiilor elementare şi discută adecvarea fiecărei metode pentru fiecare element. S-a concluzionat că prima metodă prezintă o precizie mai bună pentru măsurarea concentraţiilor tuturor elementelor analizate cu excepția fierului. 


\section{INTRODUCTION}

Water was and still is important for life and human society (Moyle and Leidy, 1992; Curtean-Bănăduc et al. 2007), and it is vital to industry, being used in industrial processes either directly, or indirectly (Nemerow, 1971; Zhou and Smith, 2002). Many rivers form important surface water sources, and may contain many salts and other elements from natural or anthropogenic sources, which vary depending on erosion of underlying geology and the nature of human activities (Ramathan et al., 2003).

Water used in industrial processes often contains harmful substances and must be treated before it is put to returned to water sources such as rivers. The textile industry is one of the most water-consuming industries, with much water being used to grow cotton or turn raw wool or nylon fibers derived from petro-chemical industries into textile products (Report EPA600, 2002; Fred Gurnham, 1985). The water required in this industry needs to be of high quality, and therefore must be treated before it is used in the industry. The waste water from the textile industry is often full of complex and diverse water pollutants such as dyes, fibers, nylon and other materials including remnant fibres (Ramathan et al., 2003). Pollutants vary from plant to plant depending on the type of fiber used, the parts of the production processes and the quality and quantity of materials (Koziorowski and Kucharski, 1987).

The effect of pollutants are broad-ranging, from organic waste that absorbs dissolved oxygen and adheres to the river bed (Cromption, 2007) to solids and coloured liquids such as oil derivates and grease floating on the surface of rivers that hinder the arrival of the sun's rays into the water and threaten aquatic life (Atkins and Lowe, 2010). Inorganic contaminants such as salts affect the water hardness and increase both salinity and the proportion of heavy elements in the water of the rivers (Zhou and Smith, 2002; Ramathan et al., 2003). The acidic and alkaline debris of pollutants affect the life of the fish in the river as the waste-water from industrial plants often affects the $\mathrm{pH}$ and presence of toxic substances, and damages sewage systems (Report EPA-600, 2002; Atkins and Lowe, 2010) is also. As materials decompose, they release hydrogen sulphide gas, affect the amount of free chlorine and reduce the selfpurification capacity of the river (Koziorowski and Kucharski, 1987).

The most important pollutants are toxic trace elements which form deposits on the surface of rivers and kill the plant and animal life by affecting water transparency and blocking the sun's rays. These effects also affect humans. We measure the extent of the environmental pollution of the waters of the river Al-Diwani, specifically pollution arising from the AlDiwani textile factory, which is a threat through its release of contaminated waste water to the Al-Diwani River (Setyorin et al., 2005; Liu and Han, 2002). We measured concentrations of elements in the water entering, the water emerging and river water near the factory by using atomic absorption technique (Atomic Absorption Spectrophotometry, AAS), which has a sensitivity and high selectivity for measuring concentrations in the samples at a wavelength appropriate for each studied element (Surard and Chiranjepri, 2005). We carried out a comparative analysis of this method against the appropriate standard spectral method for each component in the same models to demonstrate the accuracy, sensitivity and precision of the method for measurement of trace elements, and discuss the results in the context of environmental pollution caused by waste water released into the river from the factory.

\section{MATERIAL AND METHODS}

Devices used: Sensitive Balance, Sortoris, Germany, Ph-meter - knick - digital (Phmeter), Pye Unicom flame Atomic absorption Spectrophotometry, Spectrophotometry PD-303 (UV-VIS) Spectrophotometry Digital Conductivity, India, Glass. Material used: All the materials used were of a high degree of purity and equipped from companies listed in table 1 . 
Preparation of samples: 1 litre (1l) water samples were taken of wastewater and input water from the laboratory Liquidation Station at Al-Diwani textile factory for four consecutive weeks. The waste water is removed once a week from the factory, and input water is typically used for four weeks before being ejected as waste water, so this sampling period is sufficient. From each of the $1 \mathrm{l}$ samples, $200 \mathrm{ml}$ were taken and filtered by filtration paper $(0.45 \mu \mathrm{m})$ to remove waste material and to measure the concentrations of elements through atomic absorption and spectral methods. A standard solution for each ion was prepared at $10 \mathrm{ppm}$ concentration in $100 \mathrm{ml}$ of distilled water as a stock, detailed in table 2. Solutions used in spectroscopic measurements: 1-alpha-nitrous-beta-naphtol solution: Prepared by dissolution of one gm in $100 \mathrm{ml}$ acetic acid; 2-Dithiazon solution: Prepared by dissolution of $0.002 \mathrm{gm}$ in $100 \mathrm{ml}$ chloroform; 3-di methyl glyoximato (DMG solution): Prepared by dissolution of one gm in $100 \mathrm{ml}$ ethanol; 4-1.10-phenanthroline solution: Prepared by dissolution of $0.25 \mathrm{gm}$ in $100 \mathrm{ml}$ distilled water that was made acidic with $0.1 \mathrm{M}$ of hydrochloric acid.

Table 1: All the materials and the source company used in the research.

\begin{tabular}{|c|c|c|c|c|}
\hline & Material names & Formula & Purity & Source companies \\
\hline 1. & Cobalt nitrate hexhytrate & $\mathrm{Co}\left(\mathrm{NO}_{3}\right)_{2 .} 6 \mathrm{H}_{2} \mathrm{O}$ & $99.9 \%$ & Merck \\
\hline 2. & Nitric acid & $\mathrm{HNO}_{3}$ & $70 \%$ & Merck \\
\hline 3. & Di-methyl glyoximato & $\mathrm{C}_{4} \mathrm{~N}_{2} \mathrm{O}_{2} \mathrm{H}_{8}$ & $95.5 \%$ & Merck \\
\hline 4. & Nickel chloride hexhydrate & $\mathrm{NiCL}_{2} \cdot 6 \mathrm{H}_{2} \mathrm{O}$ & $99.9 \%$ & Merck \\
\hline 5. & Lead nitrate & $\mathrm{Pb}\left(\mathrm{NO}_{3}\right)_{2}$ & $98 \%$ & Merck \\
\hline 6. & - Naphthol $\beta-$ nitrose $-\alpha$ & $\mathrm{ONC}_{10} \mathrm{H}_{6} \mathrm{OH}$ & $99 \%$ & Merck \\
\hline 7. & Mercury nitrate monohydrate & $\mathrm{Hg}\left(\mathrm{NO}_{3}\right)_{2 .} \mathrm{H}_{2} \mathrm{O}$ & $99 \%$ & Fluka \\
\hline 8. & Cadmium chloride & $\mathrm{CdCL}_{2}$ & $98 \%$ & Fluka \\
\hline 9. & Copper Sulphate pentahytrate & $\mathrm{CuSO}_{4} .5 \mathrm{H}_{2} \mathrm{O}$ & $98 \%$ & Fluka \\
\hline 10. & Ferric chloride trihytrate & $\mathrm{Fe} \mathrm{CL}_{2 .} 3 \mathrm{H}_{2} \mathrm{O}$ & $98 \%$ & Fluka \\
\hline 11. & Ethanol & $\mathrm{C}_{2} \mathrm{H}_{5} \mathrm{OH}$ & $75 \%$ & Aldrich \\
\hline 12. & Chloroform & $\mathrm{CHCl}_{3}$ & $95 \%$ & Aldrich \\
\hline 13. & 1 10-phenanthroline & $\mathrm{C}_{12} \mathrm{H}_{8} \mathrm{~N}_{2}$ & $98 \%$ & Aldrich \\
\hline 14. & Carbon tetra chloride & $\mathrm{CCl}_{4}$ & $99 \%$ & Britsh Drug houses \\
\hline 15. & Sodium hydroxide & $\mathrm{NaOH}$ & $98 \%$ & Britsh Drug houses \\
\hline
\end{tabular}

Table 2: Chemical compositions and weights of materials used for standard solutions.

\begin{tabular}{|c|c|c|}
\hline Weight $(\mathrm{gm} / 100 \mathrm{ml})$ & Material & Element \\
\hline 0.0023 & $\mathrm{Ni} \mathrm{CL} 2 \cdot 6 \mathrm{H}_{2} \mathrm{O}$ & Nickel \\
\hline 0.0028 & $\mathrm{Co}\left(\mathrm{NO}_{3}\right)_{2} \cdot 6 \mathrm{H}_{2} \mathrm{O}$ & Cobalt \\
\hline 0.0034 & $\mathrm{Hg}\left(\mathrm{NO}_{3}\right)_{2} \cdot \mathrm{H}_{2} \mathrm{O}$ & Mercury \\
\hline 0.0024 & $\mathrm{Cu}\left(\mathrm{NO}_{3}\right)_{2} \cdot 5 \mathrm{H}_{2} \mathrm{O}$ & Cupper \\
\hline 0.0018 & $\mathrm{CdCl}_{2}$ & Cadmium \\
\hline 0.0033 & $\mathrm{~Pb}\left(\mathrm{NO}_{3}\right)_{2}$ & Lead \\
\hline
\end{tabular}




\section{RESULTS AND DISCUSSION}

Measured ions: calibration curve was made for each ion through the two methods (atomic absorption spectroscopic method and spectroscopic methods) appropriate for each ion.

1-lead ion $\left(\mathbf{P b}^{+2}\right)$ : Concentrations of lead in samples were measured by atomic absorption spectroscopic methods and spectroscopic methods, by calculating the absorbance of the complex lead with Dithiazon. Maximum absorbance was at $510 \mathrm{~nm}$ (Merczenko, 2005). The calibration curves are presented in figures $1 \mathrm{a}, \mathrm{b}$, and the results are presented in table 3.

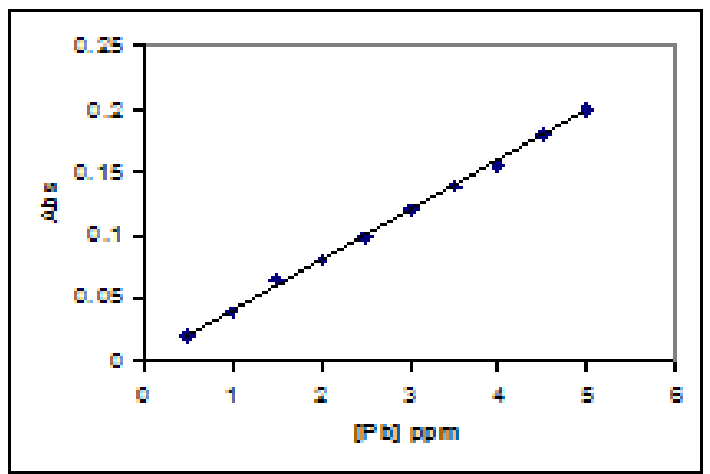

Figure 1a: Calibration curve for lead (spectroscopic method).

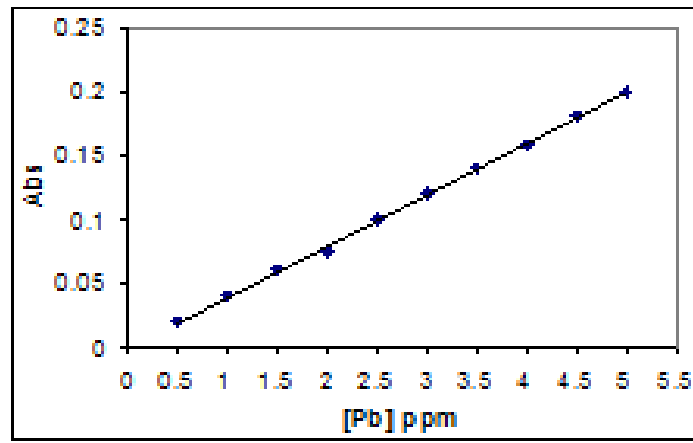

Figure 1b: Calibration curve for lead (atomic absorption method).

Table 3: Lead ion concentration in water samples.

\begin{tabular}{|c|c|c|c|c|c|c|}
\hline $\mathrm{Re} \%$ & $\mathrm{E}_{\text {rel }}$ & $\mathrm{RSD} \%$ & values (r) & $\begin{array}{c}\text { Avg. conc. of } \\
\text { element (ppm) }\end{array}$ & Method & Water type \\
\hline $98.50 \%$ & -1.50 & $1.40 \%$ & 0.9993 & 3.31 & $\begin{array}{c}\text { Atomic } \\
\text { absorption }\end{array}$ & $\begin{array}{c}\text { Waste } \\
\text { water }\end{array}$ \\
\hline $98.50 \%$ & -4.50 & $4.60 \%$ & 0.9989 & 3.38 & $\begin{array}{c}\text { spectroscopic } \\
\text { method }\end{array}$ & $\begin{array}{c}\text { Waste } \\
\text { water }\end{array}$ \\
\hline $97 \%$ & -3 & $1.51 \%$ & 0.9993 & 3.05 & $\begin{array}{c}\text { Atomic } \\
\text { absorption }\end{array}$ & $\begin{array}{c}\text { Input } \\
\text { water }\end{array}$ \\
\hline $96.50 \%$ & -3.5 & $4.20 \%$ & 0.9989 & 3 & $\begin{array}{c}\text { spectroscopic } \\
\text { method }\end{array}$ & $\begin{array}{c}\text { Input } \\
\text { water }\end{array}$ \\
\hline $98.30 \%$ & -1.70 & $1.40 \%$ & 0.9993 & 3.5 & $\begin{array}{c}\text { Atomic } \\
\text { absorption }\end{array}$ & $\begin{array}{c}\text { River } \\
\text { water }\end{array}$ \\
\hline $93.50 \%$ & -6.50 & $4.60 \%$ & 0.9989 & 3.6 & $\begin{array}{c}\text { spectroscopic } \\
\text { method }\end{array}$ & $\begin{array}{c}\text { River } \\
\text { water }\end{array}$ \\
\hline
\end{tabular}


The results (Tab. 3) note the presence of high concentrations of lead in water entering the factory and in factory waste water. The factory does not currently treat the water to remove it. The waste water contains a high concentration of lead because they use galvanized pipes, and the synthetic dyes used in textile production four-ethyl lead, a fuel derivative (AbdalRadha et al., 2002). There is, therefore, a high concentration of lead ions in the river water, at levels which are in excess of the International Standard of $0.05 \mathrm{ppm}$ for lead concentration. Lead and its compounds are toxic, and accumulations leads to brain damage, anaemia, damage to the digestive tract and kidneys, and can lead to the death of plants (Gaw and Cowana, 2007). The results presented here suggest that, based on the r correction factor, RSD\%, Erel and Re\%, the atomic absorption method gives a more accurate and sensitive estimation of the concentration of lead ions than the spectral method for all the measured samples.

2-Mercury Ion $\left(\mathrm{Hg}^{+2}\right)$ : Mercury ion concentration in the samples was measured by atomic absorption spectroscopy, a process that, for mercury, requires cold atomization. The spectroscopic method was measured by the absorbance of the complex output of mercury and dithiazon reagent with the maximum wave length at $485 \mathrm{~nm}$ (Merczenko, 2005). Figures 2a, b presents the calibration curves and the results of the analysis are shown in table 4.

The results in table 4 indicate that there is no mercury in input water samples to the factory where it is processed through the formation of complexes. However, in the factory wastewater we note the presence of very high concentrations of mercury, most likely due to the formation of complexes with the addition of chlorine in some of the industrial processes in the factory (Surard and Chiranjepri, 2005). These concentrations are well in excess of the recommended maximum concentration of mercury in surface water which is equal to $0.005 \mathrm{ppm}$. Mercury is highly toxic but commonly used in many dyes and in the synthesis of many organic compounds used in the industry (Vekhande, 2006).

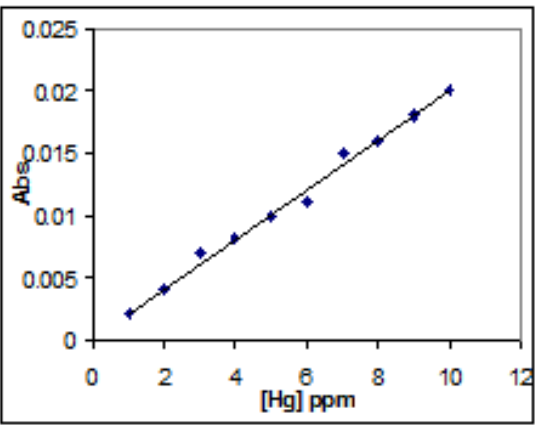

Figure 2a: Calibration curves for mercury (spectroscopic method).

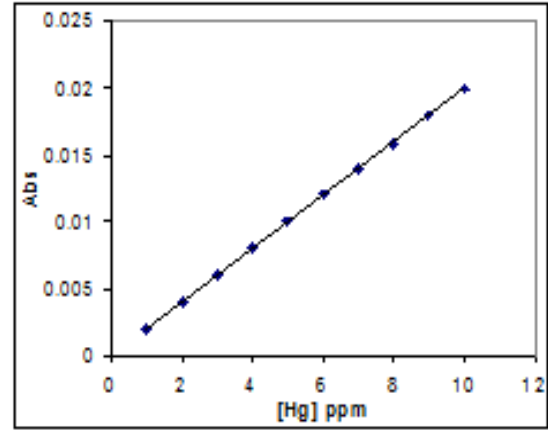

Figure 2a: Calibration curves for mercury (atomic method). 
Table 4: Mercury ion concentration in water samples.

\begin{tabular}{|c|c|c|c|c|c|c|}
\hline Re\% & $E_{\text {rel }}$ & RSD\% & $\begin{array}{c}\text { values } \\
(\mathrm{r})\end{array}$ & $\begin{array}{c}\text { Avg. } \\
\text { conc.of } \\
\text { element } \\
\text { (ppm) }\end{array}$ & Method & Water type \\
\hline $96.50 \%$ & -3.50 & $2.40 \%$ & 0.9999 & 1.18 & Atomic absorption & $\begin{array}{c}\text { Waste } \\
\text { water }\end{array}$ \\
\hline $95 \%$ & -5 & $4 \%$ & 0.9955 & 1.4 & Spectroscopic method & $\begin{array}{c}\text { Waste } \\
\text { water }\end{array}$ \\
\hline 0 & 0 & 0 & 0.9999 & ND & Atomic absorption & $\begin{array}{c}\text { Input } \\
\text { water }\end{array}$ \\
\hline 0 & 0 & 0 & 0.9955 & ND & Spectroscopic method & $\begin{array}{c}\text { Input } \\
\text { water }\end{array}$ \\
\hline $98 \%$ & -2 & $1.40 \%$ & 0.9999 & 1.14 & Atomic absorption & $\begin{array}{c}\text { River } \\
\text { water }\end{array}$ \\
\hline $96 \%$ & -4 & $3 \%$ & 0.9955 & 1.51 & Spectroscopic method & $\begin{array}{l}\text { River } \\
\text { water }\end{array}$ \\
\hline
\end{tabular}

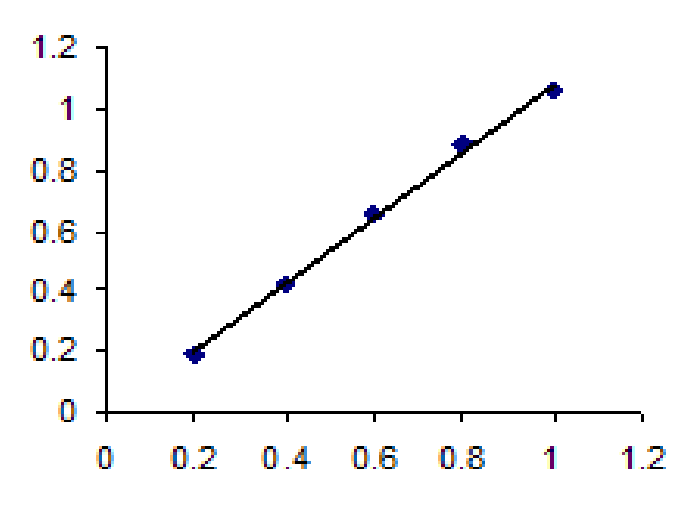

Figure 3a: Calibration curves for cadmium (spectroscopic method).

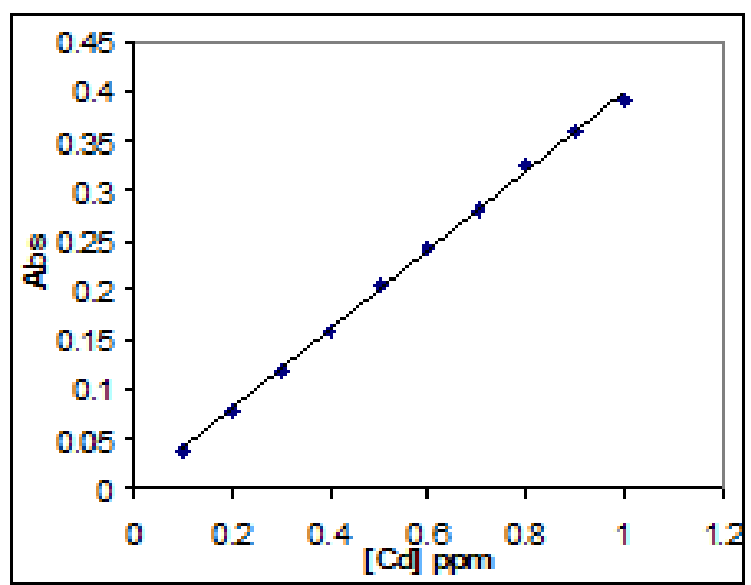

Figure 3b: Calibration curves for cadmium (atomic absorption method). 
Mercury poisoning causes flicker vertigo, lung damage, blindness and infertility and its accumulation causes brain damage (Lee, 2007). Mercury also has a significant effect on aquatic life: where it is deposited by bacteria, the alkali mercury doubles the threat in the bottoms of rivers and high concentrations (1.5 ppm or higher) will lead to the death of river fish (Al-sadai, 2009). From the results in table 4, based on the r correction factor, RSD\%, Erel and $\mathrm{Re} \%$, the atomic absorption method gives a more accurate and sensitive estimation of the concentration of mercury ions than the spectral method for all the measured samples.

3-Cadmium Ion $\left(\mathbf{C d}^{+2}\right)$ : Cadmium ion concentration was measured in the samples using atomic absorption spectroscopy and spectroscopic methods by calculating the absorbance of the complex cadmium with Dithiazon at the maximum absorbance at $520 \mathrm{~nm}$ (Merczenko, 2005). The calibration curves are shown in figures 3a, b. The results are presented in table 5.

Table 5: Cadmium ion concentration in water samples.

\begin{tabular}{|c|c|c|c|c|c|c|}
\hline $\mathrm{Re} \%$ & $\mathrm{E}_{\text {rel }}$ & $\mathrm{RSD} \%$ & $\begin{array}{c}\text { values } \\
(\mathrm{r})\end{array}$ & $\begin{array}{c}\text { Avg. conc. of } \\
\text { element (ppm) }\end{array}$ & Method & $\begin{array}{c}\text { Water } \\
\text { type }\end{array}$ \\
\hline $98.70 \%$ & -1.30 & $1.232 \%$ & 0.9994 & 0.375 & Atomic absorption & $\begin{array}{c}\text { Waste } \\
\text { water }\end{array}$ \\
\hline $98 \%$ & -2 & $3 \%$ & 0.9988 & 0.210 & Spectroscopic method & $\begin{array}{c}\text { Waste } \\
\text { water }\end{array}$ \\
\hline 0 & 0 & 0 & 0.9994 & $\mathrm{ND}$ & Atomic absorption & $\begin{array}{c}\text { Input } \\
\text { water }\end{array}$ \\
\hline 0 & 0 & 0 & 0.9988 & $\mathrm{ND}$ & Spectroscopic method & $\begin{array}{c}\text { Input } \\
\text { water }\end{array}$ \\
\hline $98 \%$ & -2 & $1.52 \%$ & 0.9994 & 0.390 & Atomic absorption & $\begin{array}{c}\text { River } \\
\text { water }\end{array}$ \\
\hline $95 \%$ & -5 & $3.10 \%$ & 0.9988 & 0.400 & Spectroscopic method & $\begin{array}{c}\text { River } \\
\text { water }\end{array}$ \\
\hline
\end{tabular}

From table 5 it is clear that there is an absence of cadmium in the input water to the factory, in part due to a treatment for cadmium by forming insoluble complexes with chlorine (Surard and Chiranjepri, 2005). However, the water waste and river water samples show the presence of high concentrations of cadmium caused by waste from the factory, at levels higher than the recommended maximum concentration of $0.04 \mathrm{ppm}$ in surface waters. These concentrations are likely to be the result of cadmium ions being present in pigments and coating materials, and being used in the composition of many plastic substances used in the industry. Cadmium forms strong bonds with carbon and is soluble in organic and inorganic solvents. Cadmium affects humans through interaction with DNA or RNA which result in effects on genes (Khlool, 2005). The accumulation of cadmium leads to the dissolution of the bones, affects the metabolism of fatty acids, affects life cycles and growth in aquatic organisms and affects plants in the aquatic environment (Surard and Chiranjepri, 2005). From the results in table 5, based on the $\mathrm{r}$ correction factor, RSD\%, Erel and $\mathrm{Re} \%$, the atomic absorption method gives a more accurate and sensitive estimation of the concentration of mercury ions than the spectral method for all the measured samples. 
4-Nickel ion I ( $\left.\mathbf{N i}^{+2}\right)$ : Nickel ion concentration was computed in the samples atomic absorption spectroscopy and spectroscopic methods by calculating the absorbance of the complex between nickel and di-methyl glyoximato (DMG) at a maximum wavelength of $445 \mathrm{~nm}$ (Merczenko, 2005). The calibration curves are shown in figures 4a, b. The results are presented in table 6 .

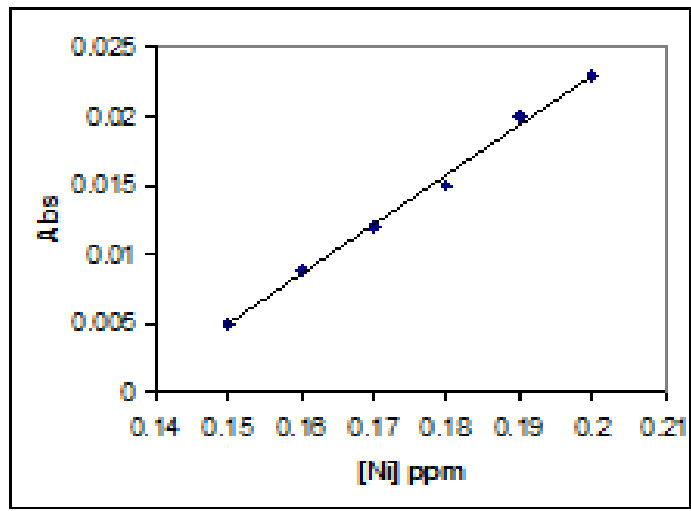

Figure 4a: Calibration curves for nickel (spectroscopic method).

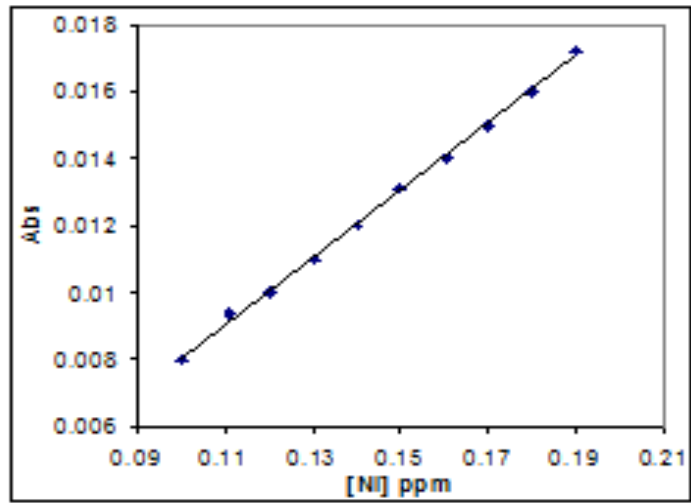

Figure 4b: Calibration curves for nickel (atomic absorption method).

Table 6: Nickel ion concentration in water samples.

\begin{tabular}{|c|c|c|c|c|c|l|}
\hline Re\% & $E_{\text {rel }}$ & RSD\% & $\begin{array}{c}\text { Avalues } \\
(\mathrm{r})\end{array}$ & $\begin{array}{c}\text { Avg. } \\
\text { conc. of } \\
\text { element } \\
(\mathrm{ppm})\end{array}$ & Method & Water type \\
\hline $98 \%$ & -2 & $1.60 \%$ & 0.9997 & 0.135 & Atomic absorption & Waste water \\
\hline $96 \%$ & -4 & $2.50 \%$ & 0.9991 & 0.14 & Spectroscopic method & Waste water \\
\hline $97 \%$ & -3 & $1.70 \%$ & 0.9997 & 0.115 & Atomic absorption & Input water \\
\hline $95.90 \%$ & -4.10 & $2.40 \%$ & 0.9991 & 0.12 & Spectroscopic method & Input water \\
\hline $98.50 \%$ & -1.50 & $2.84 \%$ & 0.9997 & 0.16 & Atomic absorption & River water \\
\hline $97 \%$ & -3 & $3.50 \%$ & 0.9991 & 0.19 & Spectroscopic method & River water \\
\hline
\end{tabular}


The results indicate that there is nickel in both input water samples and waste water samples. Of particular concern is the concentration of nickel ions in the waste water samples, which lie outside the threshold limit of $0.02 \mathrm{ppm}$ for surface water. The concentration of nickel ions in water waste is likely to be due to its use in the synthesis of dyes and in the use of many alloys (Kassam, 2005). Nickel concentrations of one ppm are deadly to aquatic environment (Allway, 2000). Nickel leads to a lack of growth, it has effects on the blood (high number of red blood cells), affects the production of protein in the kidneys (Gupta et al., 2002) and affects plant life through its influence on the solubility of ion exchange in plants (Allway, 2000). The results in table 6 indicate that, based on the correction coefficient r, RSD\%, Erel and Re\%, the atomic absorption method is more accurate and sensitive to the estimation of nickel ions than spectral methods for all the measured samples.

5-Cobalt ion $\left(\mathrm{Co}^{+2}\right)$ : Cobalt ion concentration was calculated in the samples by atomic absorption spectroscopy and spectroscopic methods by calculating the absorbance of the complex between cobalt ions and alpha-nitrous-beta-naphtol at a maximum wavelength of $415 \mathrm{~nm}$ (Merczenko, 2005). The calibration curves are presented in figures 5a, b and the results shown in table 7.

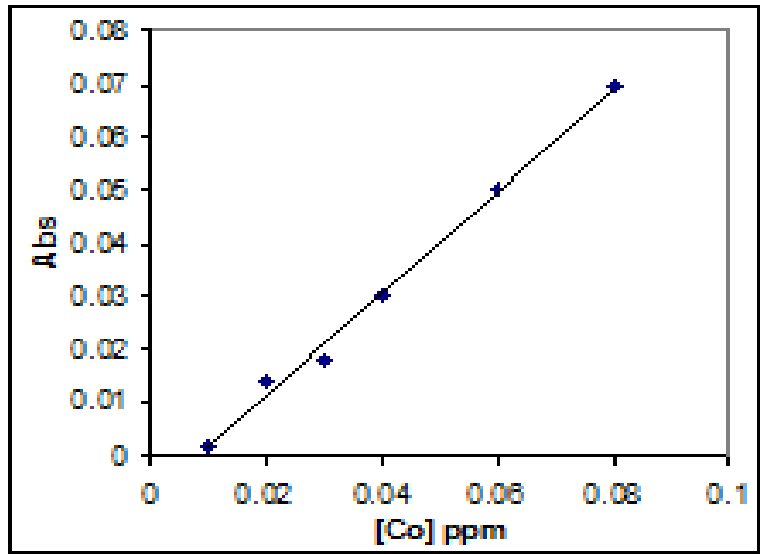

Figure 5a: Calibration curves for cobalt (spectroscopic method).

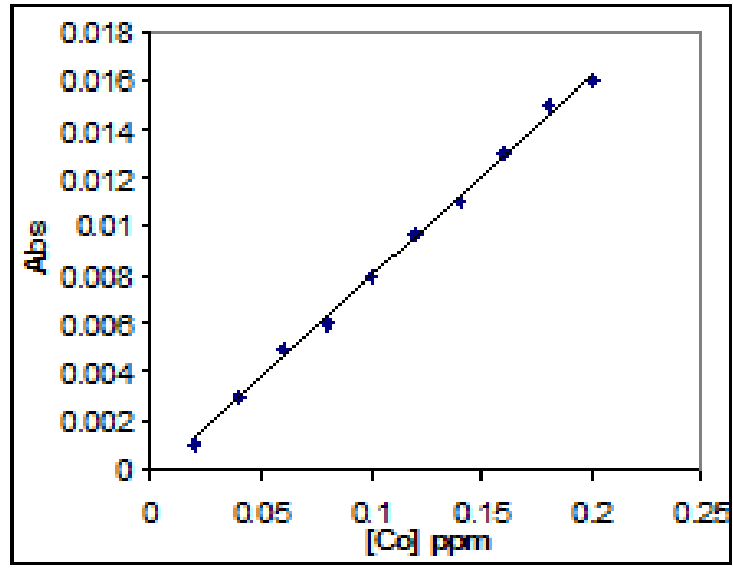

Figure 5b: Calibration curves for cobalt (atomic absorption method). 
The results indicate little cobalt entering the factory via the input water but a clear presence of cobalt in waste water and river water samples, although the concentration is within the allowable limit threshold range which is equal to $0.05 \mathrm{ppm}$. The ion enters in the steel pipe industry and in the installation of dyes used in the textile industry (Mahdi et al., 2004). It is commonly present in low concentrations in sea water and drinking water, and it forms insoluble complexes that settle to the bottom of the aquatic environment. Cobalt affects plants, animals and human growth (Sheekh et al., 2003). The results in table 7 indicate that, based on the correction coefficient $\mathrm{r}$, RSD\%, Erel and Re\%, the atomic absorption method is more accurate and sensitive to the estimation of nickel ions than spectral methods for all the measured samples.

Table 7: Cobalt concentration in water samples.

\begin{tabular}{|c|c|c|c|c|c|c|}
\hline Re\% & $\mathrm{E}_{\text {rel }}$ & $\mathrm{RSD} \%$ & $\begin{array}{c}\text { values } \\
(\mathrm{r})\end{array}$ & $\begin{array}{c}\text { Avg. conc. of } \\
\text { element } \\
(\mathrm{ppm})\end{array}$ & Method & $\begin{array}{c}\text { Water } \\
\text { type }\end{array}$ \\
\hline $97.80 \%$ & -2.20 & $3.20 \%$ & 0.9992 & 0.043 & $\begin{array}{c}\text { Atomic } \\
\text { absorption }\end{array}$ & $\begin{array}{c}\text { Waste } \\
\text { water }\end{array}$ \\
\hline $96.70 \%$ & -3.10 & $5.50 \%$ & 0.9980 & 0.73 & $\begin{array}{c}\text { Spectroscopic } \\
\text { method }\end{array}$ & $\begin{array}{c}\text { Waste } \\
\text { water }\end{array}$ \\
\hline $97.50 \%$ & -2.50 & $3.22 \%$ & 0.9992 & 0.025 & $\begin{array}{c}\text { Atomic } \\
\text { absorption }\end{array}$ & $\begin{array}{c}\text { Input } \\
\text { water }\end{array}$ \\
\hline $96.60 \%$ & -3.40 & $4.90 \%$ & 0.9980 & 0.021 & $\begin{array}{c}\text { Spectroscopic } \\
\text { method }\end{array}$ & $\begin{array}{c}\text { Input } \\
\text { water }\end{array}$ \\
\hline $97.90 \%$ & -2.10 & $3.30 \%$ & 0.9992 & 0.06 & $\begin{array}{c}\text { Atomic } \\
\text { absorption }\end{array}$ & $\begin{array}{c}\text { River } \\
\text { water }\end{array}$ \\
\hline $96 \%$ & -4 & $4.80 \%$ & 0.9980 & 0.06 & $\begin{array}{c}\text { Spectroscopic } \\
\text { method }\end{array}$ & $\begin{array}{c}\text { River } \\
\text { water }\end{array}$ \\
\hline
\end{tabular}

6-Copper ion $\left(\mathrm{Cu}^{+2}\right)$ : Copper ion concentration was calculated in the samples by atomic absorption spectroscopy and spectroscopic methods by calculating the absorbance of the complex between copper and Dithiazon at a maximum wavelength of $550 \mathrm{~nm}$ (Merczenko, 2005). The calibration curves are presented in figures $6 \mathrm{a}, \mathrm{b}$, and the results in table 8 .

Table 8 indicates that there is copper present in water entering and leaving the factory, and that the concentration of copper in the waste water is higher than that in the input water. The concentrations of copper in both waste and input water are within the range allowed for the concentration of copper in surface waters which is equal to one ppm. Copper enters the waste water through the use of copper pans, plates, copper drilling and copper cylinders used in textile printing and in paint (Purachat et al., 2001). The toxicity of copper emerges after absorption of large amounts of the element via food and from contaminated water. It primarily accumulates in the liver where it causes haemolytic issues and jaundice (Dirilgen, 2001; Zhao et al., 2001). The results in table 8 indicate that, based on the correction coefficient r, RSD\%, Erel and Re\%, the atomic absorption method is more accurate and sensitive to the estimation of nickel ions than spectral methods for all the measured samples. 


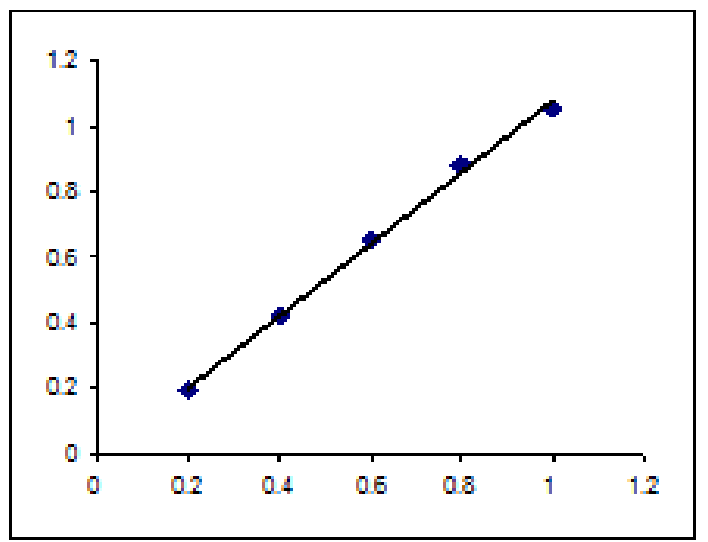

Figure 6a: Calibration curves for Copper (spectroscopic method).

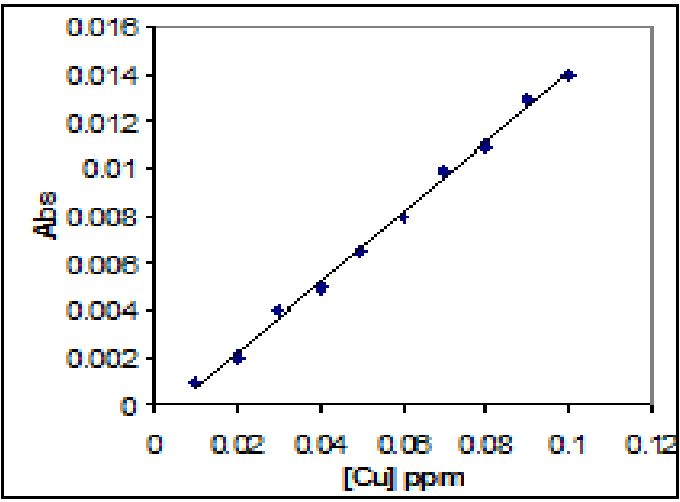

Figure 6b: Calibration curves for Copper (atomic absorption method).

Table 8: Copper ion concentration in water samples.

\begin{tabular}{|c|c|c|c|c|c|c|}
\hline Re\% & $\mathrm{E}_{\text {rel }}$ & $\mathrm{RSD} \%$ & $\begin{array}{c}\text { values } \\
(\mathrm{r})\end{array}$ & $\begin{array}{c}\text { Avg. conc. of } \\
\text { element } \\
(\mathrm{ppm})\end{array}$ & Method & $\begin{array}{c}\text { Water } \\
\text { type }\end{array}$ \\
\hline $96.50 \%$ & -3.50 & $3 \%$ & 0.9991 & 0.5 & $\begin{array}{c}\text { Atomic } \\
\text { absorption }\end{array}$ & $\begin{array}{c}\text { Waste } \\
\text { water }\end{array}$ \\
\hline $96.40 \%$ & -3.60 & $3.10 \%$ & 0.9987 & 0.41 & $\begin{array}{c}\text { Spectroscopic } \\
\text { method }\end{array}$ & $\begin{array}{c}\text { Waste } \\
\text { water }\end{array}$ \\
\hline $96.80 \%$ & -3.20 & $2.90 \%$ & 0.9991 & 0.05 & $\begin{array}{c}\text { Atomic } \\
\text { absorption }\end{array}$ & $\begin{array}{c}\text { Input } \\
\text { water }\end{array}$ \\
\hline $96.50 \%$ & -3.50 & $3.20 \%$ & 0.9987 & 0.04 & $\begin{array}{c}\text { Spectroscopic } \\
\text { method }\end{array}$ & $\begin{array}{c}\text { Input } \\
\text { water }\end{array}$ \\
\hline $96.90 \%$ & -3.10 & $3.23 \%$ & 0.9991 & 0.52 & $\begin{array}{c}\text { Atomic } \\
\text { absorption }\end{array}$ & $\begin{array}{c}\text { River } \\
\text { water }\end{array}$ \\
\hline $96.70 \%$ & -3.30 & $3.40 \%$ & 0.9987 & 0.51 & $\begin{array}{c}\text { Spectroscopic } \\
\text { method }\end{array}$ & $\begin{array}{l}\text { River } \\
\text { water }\end{array}$ \\
\hline
\end{tabular}


7-Iron ion $\left(\mathrm{Fe}^{+2}\right)$ : Iron ion concentration was calculated in the samples by atomic absorption spectroscopy and spectroscopic methods by calculating the absorbance of the complex between iron ions and 1.10-phenanthroline solution at a maximum wavelength of $512 \mathrm{~nm}$ (Merczenko, 2005). The calibration curves are presented in figures 7a, b and the results in table 9.

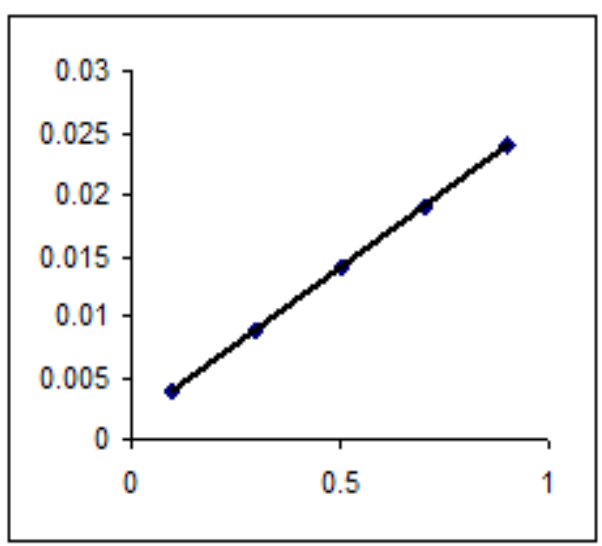

Figure 7a: Calibration curve for Iron (spectroscopic methods).

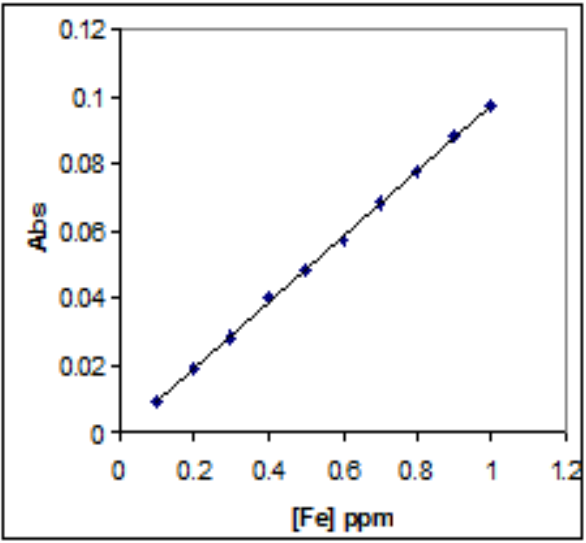

Figure 7b: Calibration curve for Iron (atomic absorption methods).

Table 9: Iron ion concentration in water samples.

\begin{tabular}{|c|c|c|c|c|c|c|}
\hline Re\% & $\mathrm{E}_{\text {rel }}$ & RSD\% & $\begin{array}{c}\text { values } \\
\text { (r) }\end{array}$ & $\begin{array}{c}\text { Avg. conc. of } \\
\text { element (ppm) }\end{array}$ & Method & $\begin{array}{c}\text { Water } \\
\text { type }\end{array}$ \\
\hline $97 \%$ & -3 & $3.29 \%$ & 0.9994 & 0.06 & $\begin{array}{c}\text { Atomic } \\
\text { absorption }\end{array}$ & $\begin{array}{c}\text { Waste } \\
\text { water }\end{array}$ \\
\hline $97.50 \%$ & -2.50 & $3.19 \%$ & 0.9996 & 0.055 & $\begin{array}{c}\text { Spectroscopic } \\
\text { method }\end{array}$ & $\begin{array}{c}\text { Waste } \\
\text { water }\end{array}$ \\
\hline $96.50 \%$ & -3.50 & $3.20 \%$ & 0.9994 & 0.02 & $\begin{array}{c}\text { Atomic } \\
\text { absorption }\end{array}$ & $\begin{array}{c}\text { Input } \\
\text { water }\end{array}$ \\
\hline $96.80 \%$ & -3.20 & $3.10 \%$ & 0.9996 & 0.03 & $\begin{array}{c}\text { Spectroscopic } \\
\text { method }\end{array}$ & $\begin{array}{c}\text { Input } \\
\text { water }\end{array}$ \\
\hline $97 \%$ & -3 & $2.95 \%$ & 0.9994 & 0.4 & $\begin{array}{c}\text { Atomic } \\
\text { absorption }\end{array}$ & $\begin{array}{c}\text { River } \\
\text { water }\end{array}$ \\
\hline $96.70 \%$ & -3.30 & $3.10 \%$ & 0.9996 & 0.2 & $\begin{array}{c}\text { Spectroscopic } \\
\text { method }\end{array}$ & $\begin{array}{c}\text { River } \\
\text { water }\end{array}$ \\
\hline
\end{tabular}


Table 9 indicates that there is a concentration of iron in the input water samples in the factory, and a high concentration of iron in water waste and in the water of the river near the factory. These concentrations are all within the range allowed for iron ion concentration in surface waters which is equal to $0.3 \mathrm{ppm}$. The presence of iron in water waste is likely to be as a result of iron pipelines transferring water within the factory and surrounding area and the rust that commonly occurs in such pipes (Jsail et al., 2003). Iron ions are commonly found in the textile industry, where iron salts are used in making many hazardous and noxious dyes notably yellow colours. Iron is also a catalyst for many processes around dyeing and colouring of textiles (Russell et al., 2007). Iron has a significant impact on the lives of plants and animals in the river when it accumulates (Jsail et al., 2003). The results in table 9 indicate that, based on the correction coefficient $\mathrm{r}$, RSD\%, Erel and Re\%, the spectral method is more accurate and sensitive to the estimation of nickel ions than the atomic absorption method for all the measured samples. This is due to the oxidation of iron $\left(\mathrm{Fe}^{+2}\right)$ to $\left(\mathrm{Fe}^{+3}\right)$ by air within the atomic absorption oven which leads to an overlap in the absorption pattern, giving a lack in accuracy of this method for this element (Gupta et al., 2002).

8-Acidic function influence (pH): The acidic function $(\mathrm{pH})$ was measured in the various water samples (input water, waste water, river water) taken from the Al-Diwani textile factory for four consecutive weeks. The ranges of $\mathrm{pH}$ values are presented in table 10 .

Table 10: pH range for samples.

\begin{tabular}{|c|c|}
\hline pH Range & Sample \\
\hline$(6.5-7.2)$ & Waste water \\
\hline$(7.39-7.75)$ & Input water \\
\hline$(7.55-8)$ & River water \\
\hline
\end{tabular}

The results indicate that the waste water is more acidic than input water, most likely due to the addition of textile products which change the relatively alkaline input water to highly acidic waste water (Jsail et al., 2003). The $\mathrm{pH}$ of the river water was within the recommended range for surface water which is equal to $8-6.5$, because the acidic waste from the factory combines with neutral substances found in the river to form neutral salts which may settle to the bottom of the river (Al-sadai, 2009).

9- Measurement of electrical conductivity: Conductivity was measured with a connectivity measuring device and calibrated with a solution of $\mathrm{KCl}$ and deionized water (Russell et al, 2007). Table 11 presents the ranges of conductivity of samples for a period of four weeks.

Table 11: Electrical conductivity Ranges for samples.

\begin{tabular}{|c|c|}
\hline Electrical conductivity ms/cm & Sample \\
\hline$(1913-1210)$ & Waste water \\
\hline$(1193-1162)$ & Input water \\
\hline$(1054-1082)$ & River water \\
\hline
\end{tabular}


The results show a significant increase in conductivity in waste water compared to input water, most likely the result of the addition of factory waste containing a high concentration of complex and metallic ions. The river water has a low conductivity due to the impact of the aquatic environment where ions are commonly precipitated to the river bottom, which reduces the conductivity of water (Al-sadai, 2009). The conductivity in all the water samples is higher than the allowable limit in surface water which is equal to $1,000 \mathrm{~ms} / \mathrm{cm}$.

\section{CONCLUSIONS}

This paper aimed to find out the extent of the environmental pollution of the waters of the river Al-Diwani by the Al-Diwani textile factory by measuring the concentration of heavy metal trace elements in the water entering and leaving the factory, and the impact of contamination on the nearby waters of the river. This was done using two different methods, atomic absorption spectroscopy and spectroscopic methods, to demonstrate which method is best suited to each ion.

The results indicate that the most concentrated heavy metal is lead (up to $3.31 \mathrm{ppm}$ ), and that the least concentrated heavy metal is cobalt (up to $0.043 \mathrm{ppm}$ ). The other measured elements, cadmium, mercury, nickel, copper and iron, fall between the concentrations of lead and cobalt. Mirroring this finding, measures of the acidic function and electrical conductivity of the samples indicated that waste water samples had the most acidic $\mathrm{pH}$ values (5.6 to 2.7) and had the highest connectivity values $(1,210-1,913 \mathrm{~ms} / \mathrm{cm})$.

It is clear from these findings that the current filter unit located in the factory waste water process is inefficient, removing only a small amount of the contaminants and leaving the majority to enter the river. This study strongly suggests a need to install a new waste treatment unit based on modern methods of treatment, such as oxidation, photo oxidation by catalysts, ion exchange, use of polymers, and deposition of strong alkalis to precipitate and thus remove heavy metal contaminants from the factory waste water and minimise the extent of river water contamination.

The use of two methods to measure concentrations of elements allows a comparison to be made between the methods. The atomic absorption method was found to be the most accurate and sensitive for all the elements except iron, when the second method, spectroscopic method, was found to be more accurate.

Given the extent of contamination from the textile factory, and the finding that different methods work better for different elements and ions, we suggest that it is important to extent this work to consider the environmental pollution from other industries, such as tyre and cement manufacture, using the methods as outlined here to ensure accuracy and sensitivity to possible contamination. We also recommend further study of this case study site, to help identify the extent of environmental contamination and to develop suitable treatment methods that promote recycling. 


\section{REFERENCES}

1. AbdaL-Radha N. A., Jaber F. A. and Habeeb H. A., 2002 - Water pollution with Trace elements, Journal of AL-Qadisiah for pure sciences, 1, 7, 89.

2. Allway B. J., 2000 - Heavy metals in Soils, John Wiley, 262.

3. Al-sadai W. G., 2009 - Ecology and pollution, 271.

4. Atkins M. H. and Lowe J. F., 2010 - Case Studies in Pollution Control Measure in the Textile Dyeing and Finishing Industries, 1st edition, William Clowes and Sons Limited, London, 62.

5. Cromption T. R., 2007 - Toxicants in the Ecosystem, John Weily and Sons Ltd.,West Sussex, England, 212.

6. Curtean-Bănăduc Angela, Bănăduc D. and Bucşa C., 2007 - Watershed Management (Transylvania, Romania) - implications, risks, solutions, Strategies to Enhance Environmental Security in Transition Countries, NATO Security trough Science Series - C: Environmental Security, Springer, ISBN 978-1-4020-5995-7, 225-238.

7. Dirilgen N., 2001 - Accumulation of heavy metals in freshwater organisms assessment of toxic interactions, Turkish Journal of Chemistry, 25, 3, 173.

8. Fred Gurnham C., 1985 - Industrial Waste Water Control, Academic Press, New York and London, 215.

9. Gaw A. R. and Cowana R. A., 2007 - Clinical Biochemistry, 45.

10. Gupta V. G., Prased R. and Kumar A., 2002 - Di benzocyclamnickel (II) as ionophore in pvcmatrix for $\mathrm{Ni}^{+2}$ selective sensor, Sonsors, 2, 384 .

11. Jsail T., Yu K. C. and Ho S. T., 2003 - Diffuse pollution Conference, Dublin, 14, 19.

12. Kassam A. A., 2005 - Spectrophotometric determination for cadmium, cobalt and zinc by new azo regent, M.SC. Thesis, Babylon University, 96.

13. Khlool M. K., 2005 - Spectrophotometric determination for nickel, copper and lead by new azo regent, M.SC. Thesis, Babylon University, 102.

14. Koziorowski B. and Kucharski J., 1987 - Industrial Waste Disposal Pergamon Press, Oxford New York, 272.

15. Lee J. D., 2007 - A new Cocise Inorganic Chemistry, Nost V. and Hold R., 390.

16. Liu C. Q. and Han G. L., 2002 - The state key laboratory of environmental Geochemistry, institute of Geochemistry, Chinese Academy of Sciences, 55, 702.

17. Mahdi A. A., Kathan S. H. and Mohammed T. A., 2004 - Spectrophotometric determination of iron in water samples and soils, Journal of AL-Qadisiah for pure sciences, 2, 9, 79.

18. Merczenko Z., 2005 - Spectrophotometric determination of elements, Halsted, press, Adivtsion of John Wiley and sonc., inc., New York, 390.

19. Moyle P. and Leidy R., 1992 - Loss of Biodiversity in Aquatic Ecosystems: Evidence from Fish Faunas, in Fiedler P. L. and Jain S. K. (eds), Conservation Biology: The Theory and Practice of Nature Conservation, Preservation and Management, New York: Chapman and Hall.

20. Nemerow N. L., 1971 - Liquid waste of Industry, Addison Wesley Publishing NY, 252.

21. Purachatetal B., Liawruangrath S., Sooksmiti P., Rattanaphani S. and Buddhasukh D., 2001 Univariate and simplex optimization for flow - injection spectrophotometric determination of copper using nitroso-R salt as complexing agent, Analytical Sciences, 17, 443.

22. Ramathan M., Al-Ghannam K. A. and Thanoon A. A., 2003 - The Industrial Chemistry and Industrial Pollution, Dar-Alhakma Publisher, Iraq, 31.

23. Report EPA-600, 2002 - U.S. Environmental Protection Agency, Cincinnati, Ohio, 2, 80.

24. Russell L. C., Mack G. and Culp G. L., 1987 - Handbook of Waste Water Treatment, Van No strand Reinhold Company, 124.

25. Setyorin D., Prihutini T. and Kurnia U., 2005 - Centra for Soil and Agroclimate and development, 2, 98, 1. 
26. Sheekh M. M., El-Naggar A. H. and El-Mazaiy S., 2003 - Effect of cobalt on growth, pigments and the photosynthetic electron transport in monoraphidium minutum and nitzchia perminuta, Brazilian Journal of Plant Physiology, 15, 3, 159.

27. Surard K. and Chiranjepri P., 2005 - Determination of cadmium in various samples of water by using atomic absorption spectroscopy, Environmental Monitoring, 1, 15.

28. Vekhande C. R., 2006 - Modern Inorganic chemistry, Oriet Longman, 29, 315.

29. Zhao S. L., Xia X. Q., Ma H. R. and Xi H. J., 1994 - Spectrophotometric determination of nickel with p-acetylarenazo, Talanta, 41, 1353.

30. Zhou H. and Smith D. W., 2002 - Advanced technologies in water and wastewater treatment, Environmental Engenering Science Journal, 1, 247. 